\section{Quadricuspid aortic valve and supracrystal interventricular communication in a Brazilian equestrian horse}

\author{
Valva Aórtica Quadricúspide e Comunicação Interventricular \\ do Tipo Supracristal em Equino Brasileiro de Hipismo
}

\author{
Jéssica do Rocio Janiszewski' (D), Andressa Duarte Lorga² (D), Anny Raissa Carolini Gomes² (D), \\ Lucimara Strugava' (D), Bruna Machado Amaral Rosa² (D), Cassiano Ricardo Rios ${ }^{3}$ (D), Marlos Gonçalves Sousa 4 (1) \& \\ Peterson Triches Dornbusch ${ }^{4}$ (ID \\ 'Veterinarian, Resident. Programa de Residência em Clínica Médica e Cirúrgica de Grandes Animais, Departamento de Medicina \\ Veterinária (DMV) Hospital Veterinário, Universidade Federal do Paraná (UFPR), Curitiba, PR, Brasil. \\ Veterinarian, Programa de Pós-Graduação em Ciências Veterinárias (PPGCV), UFPR, Curitiba, PR, Brasil. \\ ${ }^{3}$ Veterinarian, autonomus, Curitiba, PR, Brasil. \\ ${ }^{4}$ Veterinarian, DSc., DMV, UFPR, Curitiba, PR, Brasil.
}

\begin{abstract}
A 13-year-old Brazilian warmblood gelding arrived at the Veterinary Hospital of the Federal University of Paraná presenting a murmur on cardiac auscultation. At physical evaluation, an IV/VI intensity holosystolic heart murmur was heard. Due to this clinical sign, an echocardiogram examination was performed, which showed supracrystal interventricular communication, quadricuspid aortic valve (QAV) and, in Doppler evaluation, aortic reflux was noted and turbulent flow. Similar cardiac anomalies have been described in humans, hamsters, dogs, cats and shrews. However, there is only one case report in a horse and in which the equine had QAV and ventricular septal defect (VSD). Despite the congenital heart defects, the animal had no obvious signs of heart failure.
\end{abstract}

Keywords: congenital, cardiac malformation, echocardiogram.

\section{Resumo}

Um equino macho castrado de 13 anos de idade, da raça Brasileiro de Hipismo, foi atendido no Hospital Veterinário da Universidade Federal do Paraná com a queixa de possuir sopro audível à auscultação. Durante avaliação física, foi possível detectar sopro cardíaco holossistólico de intensidade IV/VI. Devido a este sinal clínico foi realizado exame de ecocardiograma, que evidenciou comunicação interventricular do tipo supracristal, valva aórtica quadricúspide (VAQ) e, em avaliação Doppler, notou-se refluxo aórtico e fluxo turbulento. Anomalias cardíacas semelhantes já foram descritas em humanos, hamster, cães, gato e musaranho. Contudo, em cavalos há apenas um relato de caso no qual o animal possuía VAQ e defeito de septo ventricular (DSV). A despeito dos defeitos congênitos cardíacos, o animal não possuía sinais evidentes de insuficiência cardíaca.

Palavras-chave: congênito, malformação cardíaca, ecocardiograma.

\section{Introduction}

The quadricuspid aortic valve (QAV) is a rare congenital malformation in all animal species. In humans, its incidence varies from $0.0059 \%$ a $0.0065 \%$, showing a higher prevalence in male individuals. Usually, people affected do not show symptoms of the disease during their youth, with signs usually appearing between 50 and 60 years of age (Salum et al., 2002; Konrad et al., 2009; Yuan, 2016). The first cases of quadricuspid aortic valve were diagnosed in autopsy exams, however, currently the diagnosis can be made in an early stage, by means of a transthoracic and transesophageal echocardiography (Konrad et al., 2009; Yuan, 2016).

In veterinary medicine, there are reports of cases of occurrence of QAV in horses, felines, dogs, hamsters and shrews (Durán, 1996; Fernández et al., 1999; Michlik et al., 2014; Nakamura et al., 2015), and signs of insufficiency may occur prior to diagnosis, or just be a result of preoperative exams (Fernández et al., 1999; Nakamura et al., 2015).
How to cite: Janiszewski, J. R., Lorga, A. D., Gomes, A. R. C., Strugava, L., Rosa, B. M. A., Rios, C. R., Sousa, M. G., \& Dornbusch, P. T. (2020). Quadricuspid aortic valve and supracrystal interventricular communication in a Brazilian equestrian horse. Brazilian Journal of Veterinary Medicine, 42, e112320. https://doi.org/10.29374/2527-2179. bjvm112320

Financial support: None

Conflict of interests: No conflict of interests declared concerning the publication of this article.

Received: May 06, 2020

Accepted: June 05, 2020.

Thestudy was carried out at Hospital Veterinário - HV, Universidade Federal do Paraná - UFPR, Curitiba, PR, Brasil.

\section{*Correspondence}

Jéssica do Rocio Janiszewski

Hospital Veterinário, Universidade Federal do Paraná - UFPR

Campus de Ciências Agrárias CEP 80035-050 - Curitiba (PR), Brasil

E-mail: jessicarociovet@gmail.com

Copyright Janiszewski et al. This is an Open Access article distributed under the terms of the Creative Commons Attribution Non-Commercial License which permits unrestricted non-commercial use, distribution, and reproduction in any medium provided the original work is properly cited. 
It is not common to perform an echocardiography in horses, especially in animals that do not show evident signs of heart disease. Since there are few reports of QAV accompanied by a ventricular septal defect (VSD) in horses, the objective was to report this unusual case, in which the two anomalies were identified together.

\section{History}

A 13-year-old Brazilian warmblood gelding equestrian horse arrived at the Veterinary Hospital of the Federal University of Paraná presenting a murmur on cardiac auscultation. During physical examination, it was possible to detect holosystolic blowing intensity IV/VI without precordial tremor in both systole and in diastole in mitral, heart rate at $24 \mathrm{bpm}$, respiratory rate at 12 breaths per minute, normal colored mucus, and capillary refill time of 2 seconds and rectal temperature of $37^{\circ} \mathrm{C}$.

Due to the presence of a murmur, the animal was submitted to echocardiographic and electrocardiographic examination. The echocardiographic examination showed normal mitral, tricuspid and pulmonary valves, left ventricle with a diameter of $11.94 \mathrm{~cm}$ in diastole and 7.76 $\mathrm{cm}$ in systole under evaluation with the M-mode. However, the aortic valve was quadricuspid (Figure 1) presenting an additional cusp of smaller size compared to the other three (type B). In Doppler evaluation, the aortic valve proved to be insufficient (Figure 2).

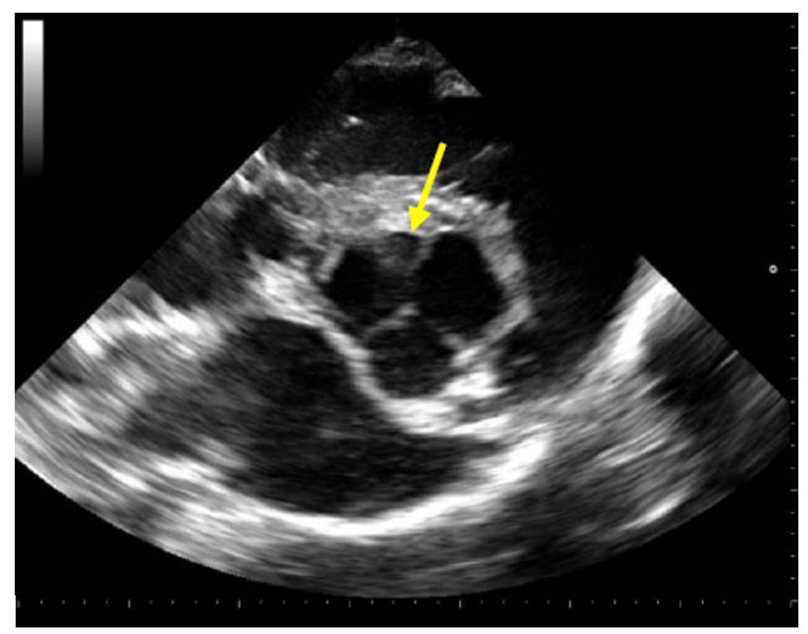

Figure 1. Cross-sectional image of the cardiac base showing quadricuspid aortic valve (additional cusp identified by the arrow).

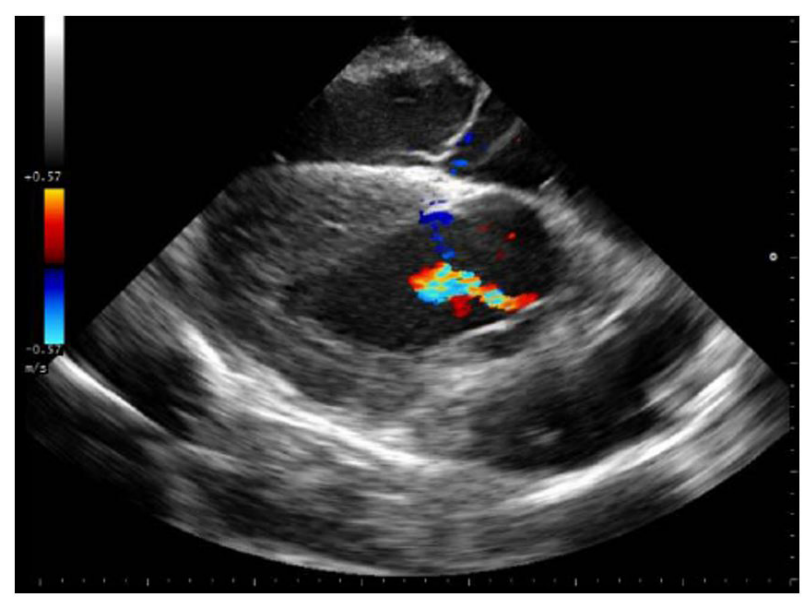

Figure 2. Longitudinal image of the LV outflow tract showing aortic insufficiency.

Another echocardiographic finding was a supracrystal interventricular communication (Figure 3, Figure 4 and Figure 5). 


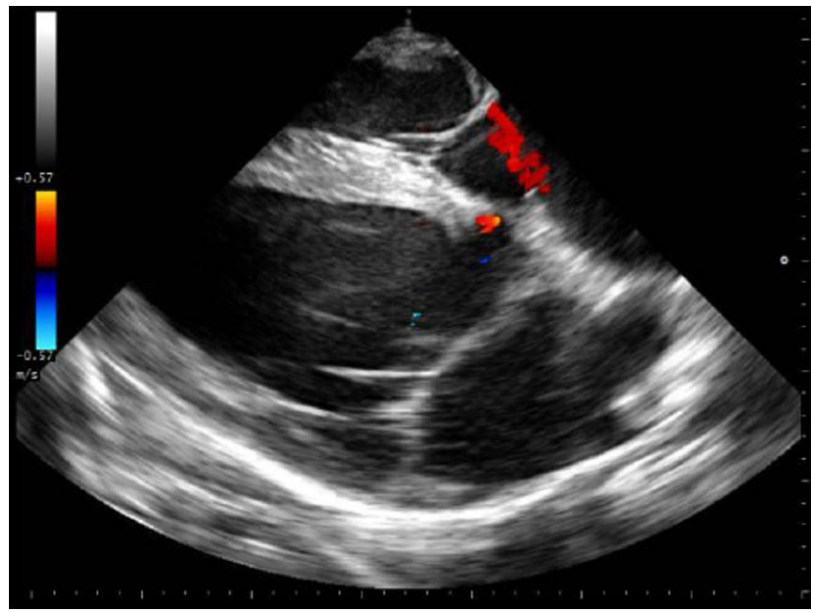

Figure 3. LV longitudinal image showing transeptal flow in the LV outflow tract region.

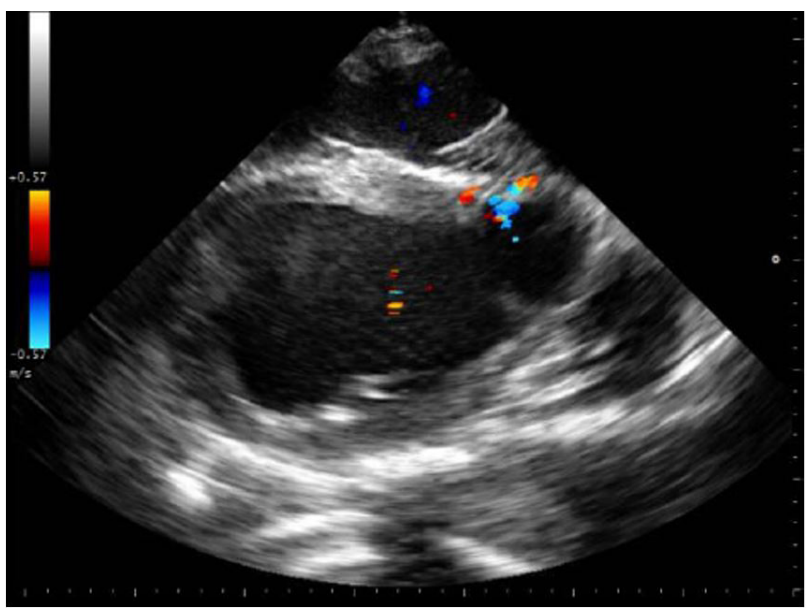

Figure 4. Oblique image of the LV showing transeptal flow in the region of the LV outflow tract.

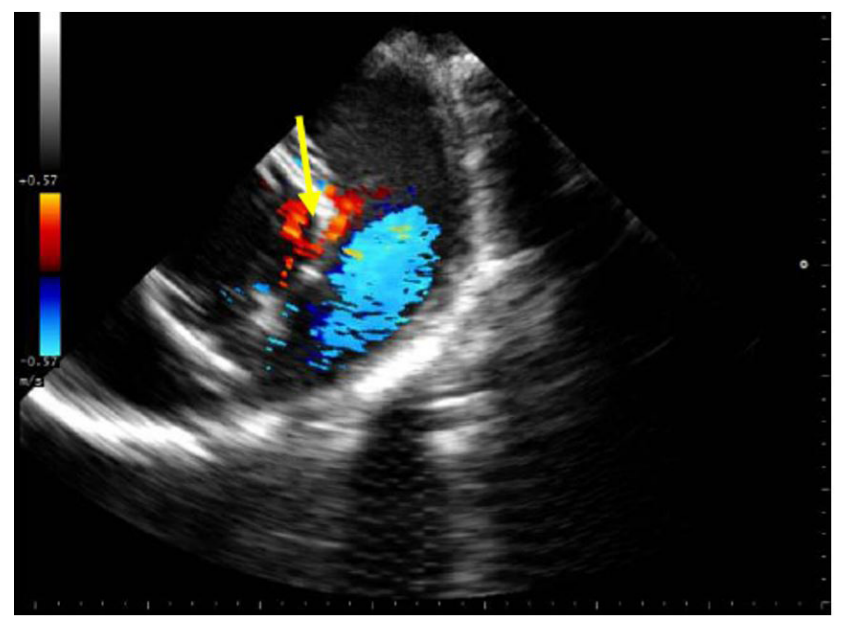

Figure 5. Cross-sectional image of the cardiac base showing the RV outflow tract and supracristral interventricular communication (arrow).

The electrocardiographic examination with the animal at rest did not reveal changes in heart rate, showing sinus rhythm and increased duration of the P wave, suggesting a moderate degree of atrial overload (Figure 6). 


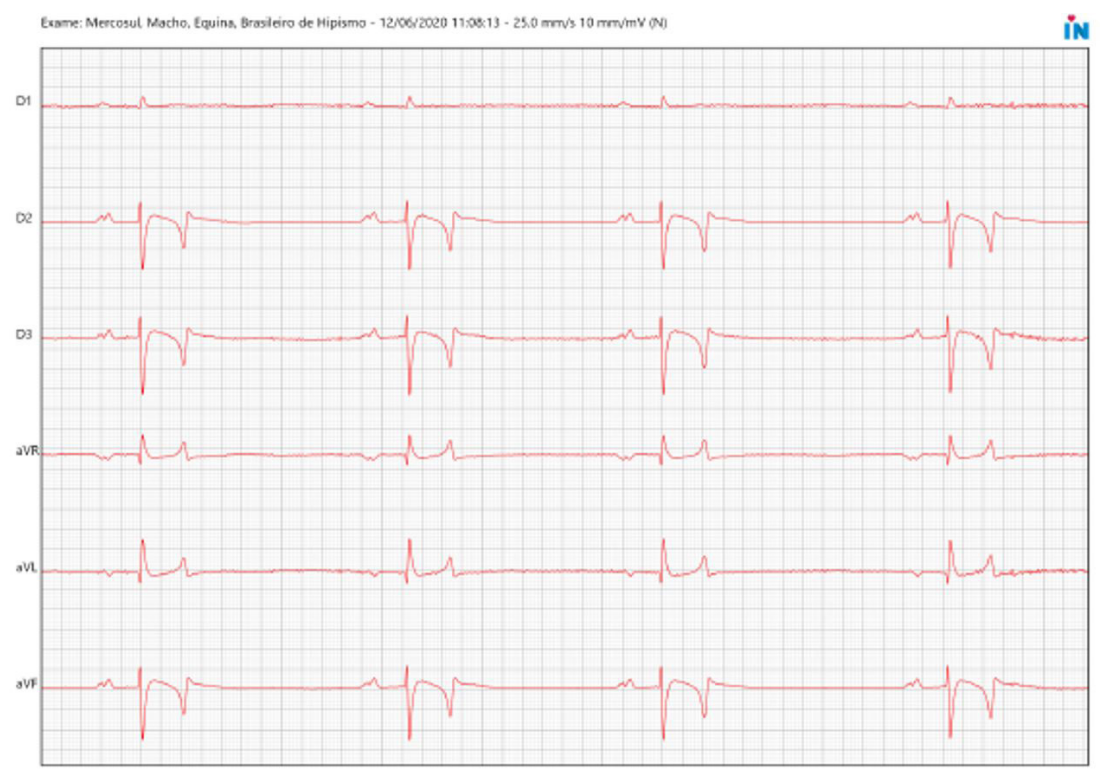

Figure 6. Electrocardiographic tracing performed with the animal at rest.

Despite documented cardiac abnormalities, the horse did not show any evident clinical signs of heart failure, such as exercise intolerance, weakness or dyspnea.

\section{Discussion}

Diseases or cardiovascular changes in horses can be well tolerated when they are tenuous However, when they are significant, they cause signs such as exercise intolerance, arrhythmia, weakness, congestive heart failure (CHF) and sudden death (Bonagura\& Reef, 2000). Hall et al. (2010), observed the prevalence of congenital heart defects in foals, describing a higher occurrence of cardiac problems in newborns of the Purebred Arab breed (39\%), with emphasis on the ventricular septal defects (VSD).

In this report case, the animal did not have clinical changes that could be attributed to cardiac anomalies, presenting only grade IV/VI holosystolic murmur. A similar case was described by Michlik et al., in which QAV and VSD were discovered through echocardiographic examination that was requested due to the detection of pansystolic murmur in a pre-anesthetic examination for elective orchiectomy. However, this horse had progressive weight loss, hypertrophic pododermatitis in the four limbs and subcutaneous edema.

The first diagnoses of this anomaly in humans occurred through necropsies in the 19th century, but currently the most widely used diagnostic methods are transthoracic and transesophageal echocardiography, the latter being considered the best method (Salum et al., 2002; Konrad et al., 2009; Brugts et al., 2015; Yuan, 2016). In horses, the available diagnostic method is transthoracic echocardiography, which was employed in the case reported.

Quadricuspid Aortic Valve is more observed in men aged between 50 and 60 years, the time of life when people with this malformation begin to show symptoms resulting from aortic insufficiency, which include dyspnea and dry cough. In addition, during physical examination, it is possible to identify grade III/VI diastolic murmur in aortic and accessory aortic foci (Salum et al., 2002; Konrad et al., 2009; Yuan, 2016).

In humans, QAV can be classified into 7 types as to the size of the cusps (Konrad et al., 2009; Yuan, 2016):

Type A: 4 equal cusps;

Type B: 3 equal cusps and one smaller one;

Type C: 2 equal major cusps and 2 equal smaller cusps;

Type D: 1 major cusp, 2 intermediate ones and 1 smaller one;

Type E: 3 equal cusps and 1 major one; 
Type F: 2 equal major cusps, 2 unequal smaller cusps;

Type G: 4 unequal cusps;

Type A and B occur more frequently in humans. In the case described here, the anomaly involved a smaller cusp and three cusps of similar size (type B).

Quadricuspid Aortic Valve can occur along with other cardiac anomalies such as changes in coronary arteries, aortic stenosis, tetralogy of Fallot, persistence of the ductus arteriosus, transposition of large arteries, mitral valve prolapse and interventricular and interatrial septal defects (Konrad et al., 2009; Yuan, 2016). In horses, all cases of VAQ already reported are concomitant with supracrystalline septal defect (Michlik et al., 2014).

\section{Conclusion}

The horse in this report was submitted to echocardiography and electrocardiography exams due to the presence of a murmur suggesting cardiac changes. Echocardiography showed the presence of QAV and VSD, which are changes compatible with the animal's life and have not yet caused systemic signs of heart failure. The electrocardiogram showed as an alteration only an increase in the duration of the P wave, suggesting the occurrence of moderate atrial overload. However, despite the morphological changes, the cardiac rhythm remained sinus.

The occurrence of QAV and VSD is rare, especially in the equine species. Due to the alterations found, it was recommended that the horse was watched with eventual echocardiogram and electrocardiogram exams in order to assess the evolution of aortic insufficiency.

\section{References}

Bonagura, J. D., \& Reef, V. B. (2000). Doenças cardiovasculares. In S. M. Reed \& W. M. Bayly (Eds.), Medicina interna equina (1. ed. pp. 250-289). Rio de Janeiro: Guanabara Koogan.

Brugts, J. J., Cuypers, J. A. A. E., Polak, P., Ouhlous, M., Van de Woestijne, P., Wessels, M., \& Roos-Hesselink, J. (2015). Quadricuspid aortic valve and anomalous systemic venous connection in a patient with cat-eye syndrome. Circulation, 131(13), 1225-1227. http://dx.doi.org/10.1161/CIRCULATIONAHA.114.013290. PMid:25825400.

Durán, A. C. (1996). Quadricuspid aortic valve and single coronary artery is a greater white-toothed shrew, Crocidura russula. Journal of Wildlife Diseases, 32(4), 658-660. http://dx.doi.org/10.7589/0090-3558-32.4.658. PMid:9359065.

Fernández, B., Durán, A. C., Martire, A., López, D., \& Sans-Coma, V. (1999). New embriological evidence for the formation of quadricuspid aortic valves in the syrian hamster (Mesocricetus auratus). Journal of Comparative Pathology, 121(1), 89-94. http://dx.doi.org/10.1053/jcpa.1998.0299. PMid:10373298.

Hall, T. L., Magdesian, K. G., \& Kittleson, M. D. (2010). Congenital cardiac defects in neonatal foals: 18 cases. Journal of Veterinary Internal Medicine, 24(1), 206-212. http://dx.doi.org/10.1111/j.1939-1676.2009.0445.x. PMid:20391638.

Konrad, R., Costa, M. N. S., \& Salamé, C. K. (2009). Valva aórtica quadricúspide: uma revisão completa. Revista Brasileira de Ecocardiografia e Imagem Cardiovascular, 22(3), 39-52.

Michlik, K. M., Biazik, A. K., Henklewski, R. Z., Szmigielska, M. A., Nicpon, J. M., \& Paslawska, U. (2014). Quadricuspid aortic valve and a ventricular septal defect in a Horse. BMC Veterinary Research, 10(1), 142. http://dx.doi. org/10.1186/1746-6148-10-142. PMid:24981768.

Nakamura, T., Sawada, T., \& Takagi, M. (2015). Incidental echocardiographic findings of a quadricuspid aortic valve associated with aortic regurgitation in a cat. Journal of Feline Medicine and Surgery Open Reports, 1(2), 1-4. http://dx.doi.org/10.1177/2055116915596356. PMid:28491375.

Salum, M. A., Wandeck, K. S., Kalil, M., Oliveira, R. N. F., \& Vieira, L. V. (2002). Insuficiência valvar aórtica por valva quadricúspide. Revista Brasileira de Cirurgia Cardiovascular, 17(1), 99-101. http://dx.doi.org/10.1590/ S0102-76382002000100014.

Yuan, S. M. (2016). Quadricuspid aortic valve: a comprehensive review. Revista Brasileira de Cirurgia Cardiovascular, 31(6), 454-460. PMid:28076624. 